\title{
Five-year Record of Black Carbon Concentrations in Urban Wanzhou, Sichuan Basin, China
}

\author{
Yimin Huang1, Liuyi Zhang',2, Yang Qiü, Yang Chen², Guangming Shi ${ }^{3 *}$, Tingzhen Li ${ }^{1}$, \\ Lei Zhang', Fumo Yang, ${ }^{1,2,3^{*}}$
}

\author{
${ }^{1}$ Key Laboratory of Water Environment Evolution and Pollution Control in Three Gorges Reservoir, Chongqing Three \\ Gorges University, Chongqing 404100, China \\ ${ }^{2}$ Chongqing Institute of Green and Intelligent Technology, Chinese Academy of Sciences, Chongqing 400714, China \\ ${ }^{3}$ National Engineering Research Center for Flue Gas Desulfurization, Department of Environmental Science and \\ Engineering, Sichuan University, Chengdu
}

\begin{abstract}
The atmospheric fine particle black carbon (BC) was measured from June 2013 till February 2018 in Wanzhou District, the second largest metropolitan area in Chongqing Municipality, China, which is located in the eastern Sichuan Basin. The average daily concentration ranged from 0.5 to $10.4 \mu \mathrm{g} \mathrm{m}^{-3}$, with a mean of $4.4 \pm 2.2 \mu \mathrm{g} \mathrm{m}^{-3}$, and the annual mean displayed a significantly decreasing trend, from $5.3 \mu \mathrm{g} \mathrm{m}^{-3}$ in 2013 to $3.7 \mu \mathrm{g} \mathrm{m}^{-3}$ in 2017 . The frequency distribution of the average daily concentrations during the years 2014-2017 skewed toward lower values (compared to the rest of the study period), with over $60 \%$ falling between 1 and $5 \mu \mathrm{g} \mathrm{m}^{-3}$. The BC exhibited a seasonal pattern, with the highest concentrations being reported during winter, followed by spring and fall, and the lowest ones during summer, as well as a double-peaked diel variability all year round, with a morning peak occurring between 07:00 and 09:00 and an evening peak between 19:00 and 21:00. Furthermore, the concentration was negatively correlated with the planetary boundary layer (PBL) height and influenced by the strong scavenging effect of precipitation. An inverse relationship between the concentration and the wind speed was observed when the latter was below $2.0 \mathrm{~m} \mathrm{~s}^{-1}$. The wind direction also affected the concentration, with easterly and southeasterly winds accompanying higher levels of $\mathrm{BC}$ regardless of the season.
\end{abstract}

Keywords: Black carbon; Seasonal variation; Diel variation; Meteorological parameters.

\section{INTRODUCTION}

Black carbon (BC), primarily originating from incomplete combustion of fossil fuel and biomass burning, is one of the important components in atmospheric aerosol, and has strong absorption of light (Jacobson, 2001; Ramanathan and Carmichael, 2008; Chow et al., 2009; Tian et al., 2018). In recent years, $\mathrm{BC}$ has attracted extensive attention because of its important effects on climate (Jacobson, 2002; Chung and Seinfeld, 2005; Schmidt, 2011), environment (Ramachandran and Rajesh, 2007; Huang et al., 2012) and human health (Kopp and Mauzerall, 2010; Janssen et al., 2011; Farzad et al., 2020). According to researches on global climate change, absorption of BC accounts for $80-90 \%$ of aerosols' contribution to global warming (Chung and Seinfeld, 2005; Kopp and Mauzerall,

\footnotetext{
* Corresponding author.

Tel.: +923009189301; Fax: +925822960402

E-mail address: shigm@scu.edu.cn (G. Shi);

fmyang@cigit.ac.cn (F. Yang)
}

2010; Rai et al., 2019). BC aerosol is considered to be the second largest contributor to anthropogenic radiative forcing after $\mathrm{CO}_{2}$ (Jacobson, 2002; Panicker et al., 2013). In addition to enhancing the absorption of solar radiation, $\mathrm{BC}$ in clouds and aerosols also accelerates cloud evaporation rate, thus changing the duration of cloud existence (Quaas, 2011; Dalirian et al., 2018). BC can heat the air to alter the stability and vertical movement of the regional atmosphere, thus having an important impact on large-scale air circulation and water circulation with implication on crop yield reduction (Chameides et al., 1999; Menon et al., 2002; Richardson et al., 2018). BC is mainly present in fine particles in the urban environment, and can be inhaled into the human body and cause adverse health effects on the respiratory system (Sahu et al., 2011; Wang et al., 2011; Jung et al., 2017).

Research on $\mathrm{BC}$ has particular importance in China because the country has been regarded as the largest emitter of BC in the world (Novakov et al., 2003; Bond et al., 2007; Ramanathan and Carmichael, 2008; Zhou et al., 2018). BC emissions in China roughly accounted for one fourth of the global anthropogenic sources (Street et al., 2001). Numerous studies on BC have been conducted in Chinese megacities, 
such as Beijing (Chen et al., 2016; Ji et al., 2016; Wang et al., 2016; Ji et al., 2017, 2019b; Liu et al., 2019), Shanghai (Feng et al., 2014; Peng et al., 2019), Guangzhou (Chen et al., 2014; Sun et al., 2020), Nanjing (Zhuang et al., 2014; Xiao et al., 2016), Xi'an (Cao et al., 2009; Wang et al., 2015a; Zhang et al., 2015; Zhang et al., 2018). Collectively, these studies produced valuable data on the distribution of $\mathrm{BC}$ in China, and also provided results on BC's optical property and radiative forcing. However, measurements from aforementioned studies were mostly short-term, and $\mathrm{BC}$ data of southwest China remains scarce.

Chongqing Municipality of southwestern China is known for its position at the hinterland of the Three Gorges Reservoir (TGR) on the Yangtze River. Wanzhou, situated in the eastern margin of the Sichuan Basin, is a district located $230 \mathrm{~km}$ away from downtown Chongqing. Wanzhou covers an area of $3457 \mathrm{~km}^{2}$ and has a registered population of approximately 1.8 million at the end of 2017 (Introduction to Wanzhou, http://www.wz.gov.cn/zjwz/wzjj/202003/t202 00331_6849138.html). In recent years, the acceleration of urbanization and energy consumption growth in Wanzhou together increased the amount of air pollutant emission, threatening local air quality. In 2013, Chinese government issued Air Pollution Prevention and Control Action Plan (2013-2017) with aggressive measures starting in October 2013. Since then, Chongqing Municipal Government has adopted a series of corresponding measures to improve the city's air quality. Studying BC, a product of fossil fuel combustion and biomass burning, can shed light on the effectiveness of these emission control measures. However, to date no publicized data is available for BC aerosol in Wanzhou. In this study, we conducted continuous measurement of $\mathrm{BC}$ at an urban site in Wanzhou from June 1, 2013, to February 28, 2018. The purposes of this study are: 1) to evaluate the temporal variability of $\mathrm{BC}$ in Wanzhou, 2) to explore the correlation between $\mathrm{BC}$ and meteorological factors, and 3) to investigate the possible emission sources of $\mathrm{BC}$.

\section{METHODS}

\section{Site Description}

$\mathrm{BC}$ mass concentration was measured on the rooftop of the Experimental Building $\left(30.79^{\circ} \mathrm{N}, 108.37^{\circ} \mathrm{E}\right)$ on Chongqing Three Georges University campus, at a height about $27 \mathrm{~m}$ above the ground (Fig. 1). Surrounding the site are residences, restaurants, and shops. At about $150 \mathrm{~m}$ east of the measurement site lies a major road, Shalong Road. There is no major stationary pollution source within $1 \mathrm{~km}$ around the sampling site. This site represents a mixed residential, traffic, and commercial environments of urban area in Wanzhou.

\section{Black Carbon Measurement}

$\mathrm{BC}$ concentration was monitored using a Thermo Carusso Model 5012 Multi-Angle Absorption Photometer (MAAP). The MAAP was equipped with an additional impactor system removing particles with aerodynamic diameter larger than $2.5 \mu \mathrm{m}$. The sampling flow of the instrument was maintained at $16.7 \mathrm{~L} \mathrm{~min}^{-1}$ at ambient temperature and pressure. Briefly, the instrument collected aerosol particles on a glass-fiber tape and measured light attenuation caused by the sampled particles. More detailed information about the $\mathrm{BC}$ analysis protocol is provided in the study of Kanaya et al. (2013). The time of day (hour) referred to throughout this paper is the starting time of each hourly measurement at local time. The study period was June 1, 2013, to February 28, 2018. Yearly sampling campaigns were conducted during the following periods: June 2013 to February 28, 2014; March 1, 2014, to February 28, 2015; March 1, 2015, to February 29, 2016; March 1, 2016, to February 28, 2017; and March 1, 2017, to February 28, 2018.

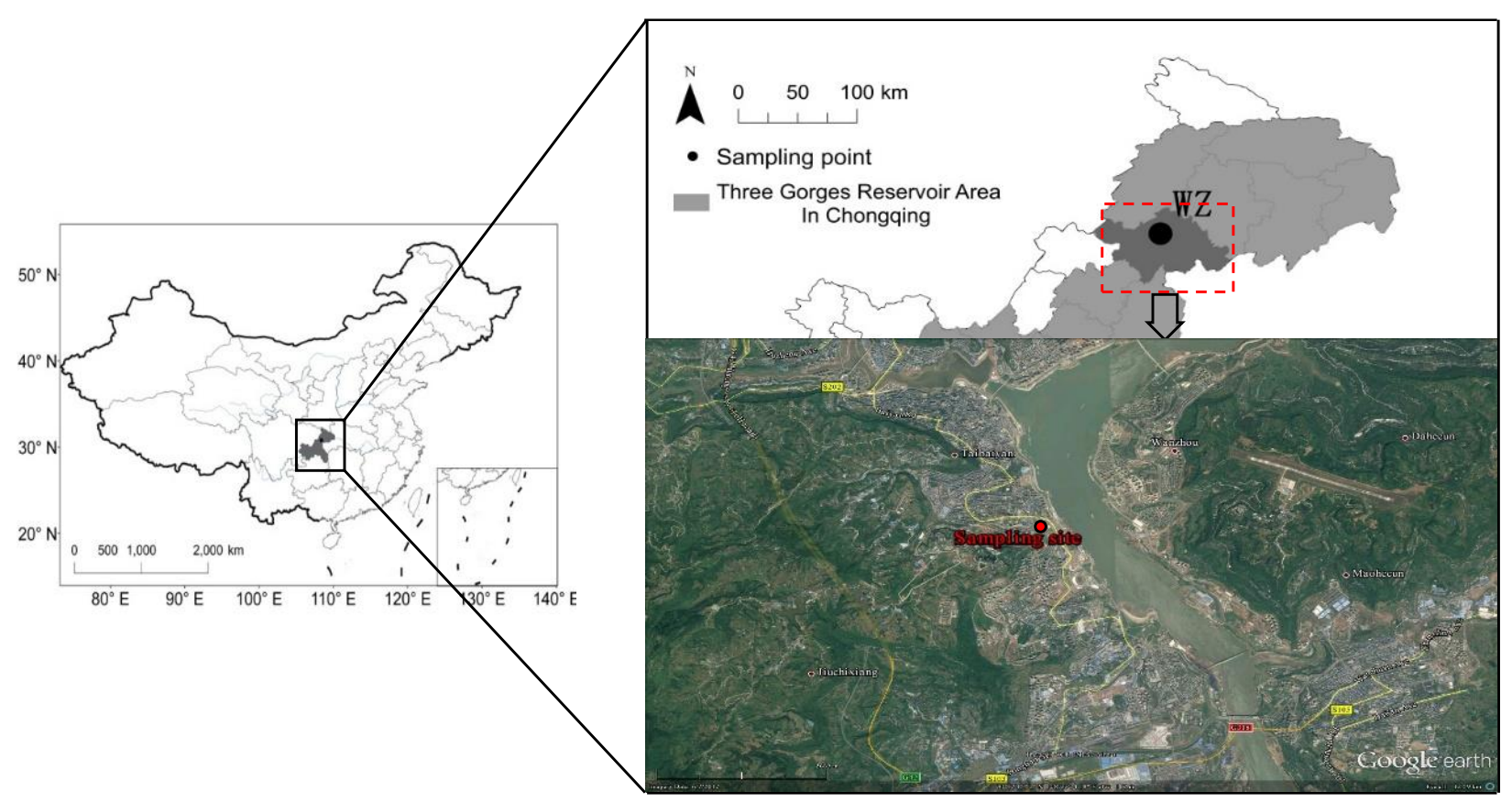

Fig. 1. Location of the sampling site in Wanzhou. 


\section{Meteorological Data}

Meteorological parameters (wind speed and direction) were collected simultaneously with $\mathrm{BC}$ monitoring using a miniature weather instrument (WS500-UMB; Lufft Corp., Germany). No direct measurement was available for planetary boundary layer (PBL) heights and precipitation during the period of $\mathrm{BC}$ measurement; we used the closest grid value of the reanalysis PBL height and precipitation to the Wanzhou as the real PBL height and precipitation. The PBL heights and precipitation during the study period were calculated by the U.S. National Oceanic and Atmospheric Administration (NOAA) READY archived meteorological data (http://www.arl.noaa.gov/ready/hysplit4.html). The program used the archived dataset GDAS $\left(1^{\circ}, 3-\mathrm{h}\right.$, global) based on the average value of Coordinated Universal Time (UTC), and the time series of calculated daily PBL heights were obtained. All UTC values were converted to local time.

\section{RESULTS AND DISCUSSIONS}

\section{BC Concentration and Variability}

Daily average BC concentration from June 1, 2013, to February 28, 2018, in Wanzhou ranged from 0.5 to $10.4 \mu \mathrm{g} \mathrm{m}^{-3}$, with a mean level of $4.4 \pm 2.2 \mu \mathrm{g} \mathrm{m}^{-3}$, implying a dramatic day-to-day variation (Fig. 2). The annual average concentration of $\mathrm{BC}$ is shown in Table 1. There was a decreasing trend of the annual mean $\mathrm{BC}$ concentration, which dropped from $5.3 \mu \mathrm{g} \mathrm{m}^{-3}$ in 2013 to $3.7 \mu \mathrm{g} \mathrm{m}^{-3}$ in 2017 (30\% reduction). Overall, at the $95 \%$ confidence level, the annual mean BC decreased by $0.33 \mu \mathrm{g} \mathrm{m}^{-3}$ year $^{-1}$ from 2013 to 2017 . The decline in $\mathrm{BC}$ concentrations is closely associated with various policy interventions taken at Chongqing. As part of mitigation implementation to control traffic pollution, Chongqing eliminated 0.26 million yellow-label cars and outdated vehicles between 2013 and 2017, while adopting Chinese national Stage V standard for diesel and gasoline vehicles and eliminating the sale and use of substandard oil. Additionally, the government had designated prohibited areas (nearly $4000 \mathrm{~m}^{2}$ ) for high emission non-road mobile machinery (NRMM) and strengthened the supervision of NRMM usage in these areas. The total energy consumption in Chongqing accounted for 72.5 and 84.5 million tons of standard coal equivalent (SCE) in 2013 and 2017, respectively. However, the proportion of coal consumption in total energy consumption dropped from $63.2 \%$ in 2013 to $53.8 \%$ in 2017. Coal has been gradually replaced by natural gas and other cleaner energy in Chongqing (Chongqing environment statement in 2017, http://sthjj.cq.gov.cn/hjzl_249/hjzkgb/20 1912/P020191228643991023980.pdf). At the same time, Chongqing had closed some heavily polluting industries, had renovated coal-fired boilers with clean energy, and had promoted the ultra-low emission transformation of coalfired power plants. Additional mitigation measures were applied for curbing domestic pollution. For example, it had reformed the lampblack emission from catering business and canteens of government and public institutions, and had intensified law enforcement on illegal activities such as burning straw, garbage, and barbecuing in the open air. It could be inferred that $\mathrm{BC}$ concentration reduction over the past few years in Wanzhou might be related to the implementation of these governmental mitigation measures.

Fig. 3 shows the frequency distributions of daily BC concentrations between 2014 and 2017. BC concentration mostly occurred between 1 and $5 \mu \mathrm{g} \mathrm{m} \mathrm{m}^{-3}$, accounting for

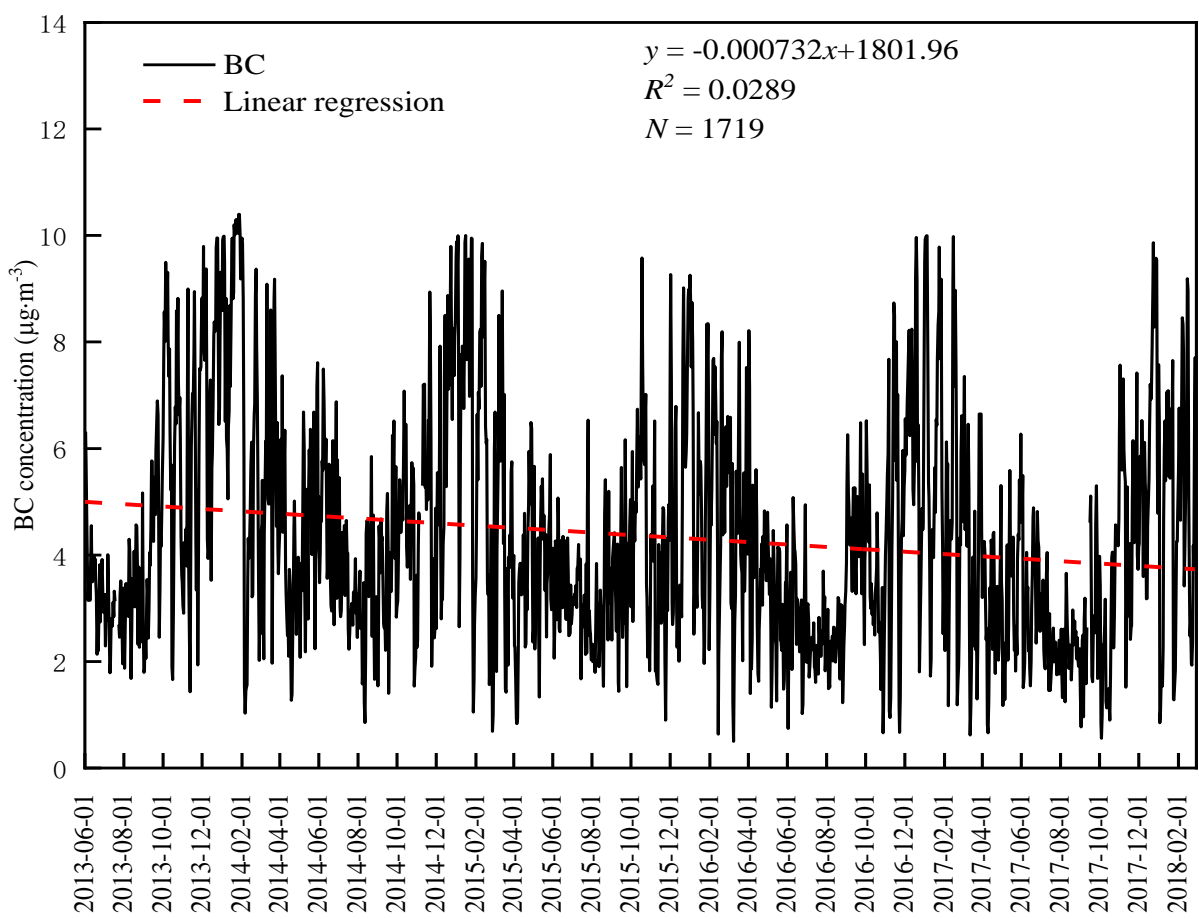

Fig. 2. Temporal variation of daily BC concentration (black line) from June 1, 2013, to February 28, 2018. The red dash line implies the linear regression trend of $\mathrm{BC}$ concentration. 
Table 1. BC concentration in $\mathrm{PM}_{2.5}$ in Wanzhou and the comparison with other sites in China.

\begin{tabular}{|c|c|c|c|c|}
\hline Site & Type & Time period & Concentration $\left(\mu \mathrm{g} \mathrm{m}^{-3}\right)$ & Reference \\
\hline \multirow[t]{5}{*}{ Wanzhou } & Urban, small city & Jun 2013-Feb 2014 & $5.3 \pm 2.6$ & This study \\
\hline & & Mar 2014-Feb 2015 & $4.8 \pm 2.1$ & \\
\hline & & Mar 2015-Feb 2016 & $4.2 \pm 1.8$ & \\
\hline & & Mar 2016-Feb 2017 & $4.1 \pm 2.1$ & \\
\hline & & Mar 2017-Feb 2018 & $3.7 \pm 1.9$ & \\
\hline Fuling & Urban, small city & Jan 2015-Dec 2015 & $3.2 \pm 2.9$ & This study \\
\hline Chongqing & Urban, large city & Jan 2012-Dec 2012 & $5.9 \pm 2.7$ & Zhang et al. (2014) \\
\hline Chengdu & Urban, large city & Sep 2013-Jul 2014 & 7.32 & Sun et al. (2016) \\
\hline Guizhou & Urban, large city & $2012-2013$ & 7.1 & Liu et al. (2018) \\
\hline Beijing & Urban, large city & Feb 2005-Dec 2013 & 4.3 & Chen et al. (2016) \\
\hline Beijing & Suburban, large city & Jan 2014-Dec 2014 & $4.4 \pm 3.7$ & Ji et al. (2017) \\
\hline Shijiazhuang & Urban, large city & Dec 2016-Nov 2017 & $5.4 \pm 6.5$ & Ji et al. (2019a) \\
\hline Nanjing & Urban, large city & Jan 2012-Dec 2012 & $4.2 \pm 2.7$ & Zhuang et al. (2014) \\
\hline Nanjing & Suburban, large city & Jan 2015-Oct 2015 & $2.5 \pm 1.8$ & Xiao et al. (2016) \\
\hline Shanghai & Urban, large city & Jan 2010-Dec 2010 & $3.8 \pm 2.3$ & Feng et al. (2014) \\
\hline Xi'an & Urban, large city & Sep 2003-Aug 2005 & $14.7 \pm 9.5$ & Cao et al. (2009) \\
\hline Handan & Urban, medium city & Mar 2013-Feb 2017 & 7.41 & Qi et al. (2018) \\
\hline Waliguan & Global background & Jan 2006-Dec 2006 & $0.05-1.37$ & Zhao et al. (2008) \\
\hline
\end{tabular}

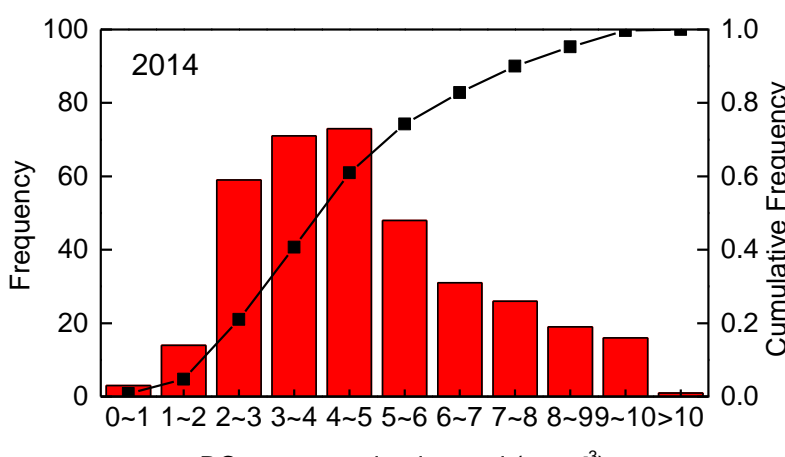

$\mathrm{BC}$ concentration interval $\left(\mu \mathrm{g} \cdot \mathrm{m}^{-3}\right)$

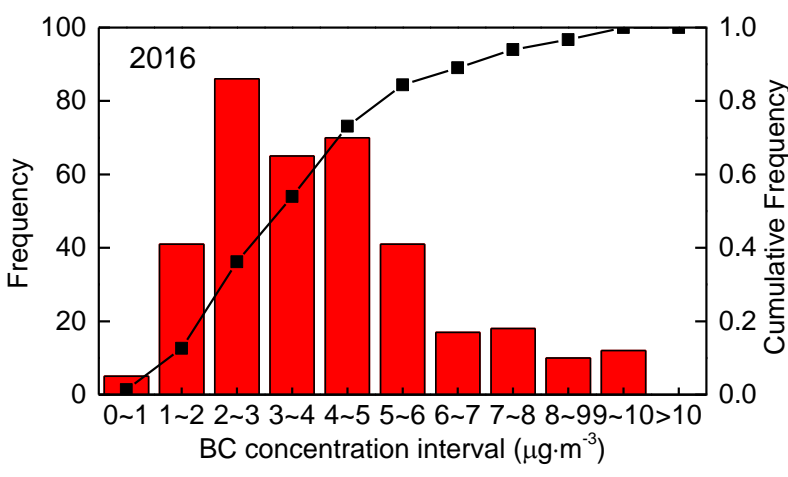

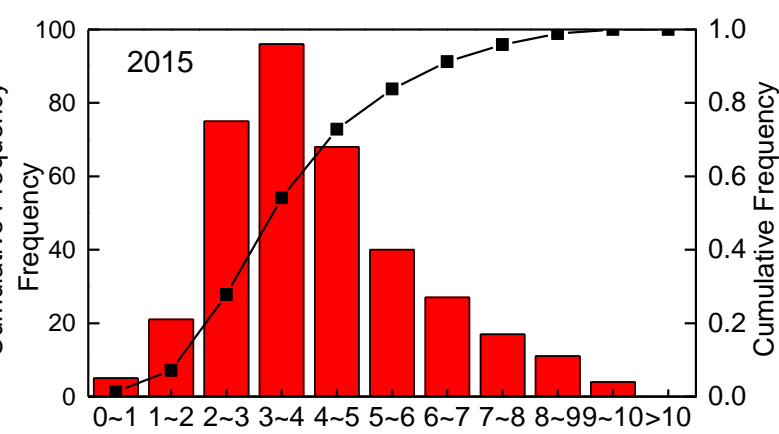

$\mathrm{BC}$ concentration interval $\left(\mu \mathrm{g} \cdot \mathrm{m}^{-3}\right)$

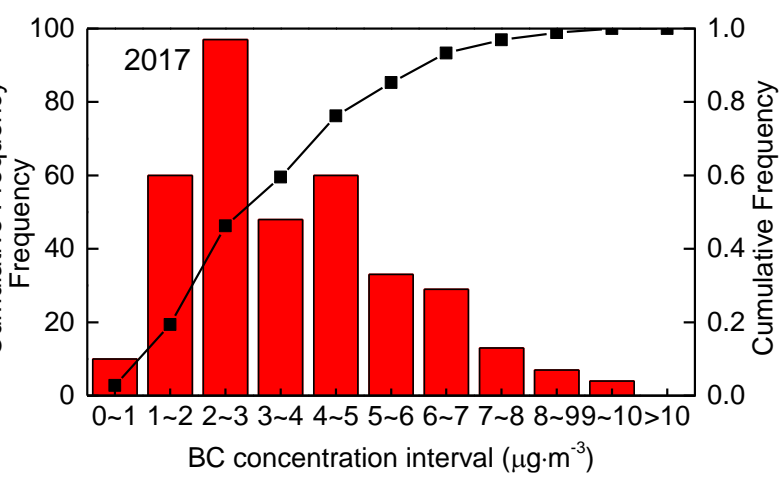

Fig. 3. Frequency distributions of daily BC concentrations from 2014 to 2017.

$60 \%$ in $2014,71 \%$ in $2015,72 \%$ in 2016 , and $73 \%$ in 2017. The maximum frequencies occurred at 4-5 $\mu \mathrm{g} \mathrm{m} \mathrm{m}^{-3}, 3-$ $4 \mu \mathrm{g} \mathrm{m}^{-3}, 2-3 \mu \mathrm{g} \mathrm{m}^{-3}$, and $1-2 \mu \mathrm{g} \mathrm{m}^{-3}$ between 2014 and 2017. These frequencies accounted for $20 \%$ of total $\mathrm{BC}$ concentrations in $2014,26 \%$ in $2015,24 \%$ in 2016 , and $27 \%$ in 2017. The frequency of BC concentrations between 6 and $10 \mu \mathrm{g} \mathrm{m}^{-3}$ decreased from $25 \%$ in 2014 to $14 \%$ in 2017. This suggests that daily BC distributions skewed towards lower concentrations from 2014 to 2017.

The mean BC concentration in Wanzhou was lower than that of downtown Chongqing and other major cities in China, e.g., Xi'an, Shijiazhuang, Chengdu, Guizhou, and Handan (Table 1). However, the BC concentration reported by this study was higher than the urban site of another district of Chongqing Municipality named Fuling $\left(29.75^{\circ} \mathrm{N}, 107.27^{\circ} \mathrm{E}\right)$, which is about $157 \mathrm{~km}$ southwest of Wanzhou and comparable to Wanzhou with regard to traffic, population and economy. Moreover, BC concentration measured in this study was comparable with urban sites of Beijing and Nanjing. In comparison to global background site (Waliguan), BC 
pollution in Wanzhou was worse. Overall, BC concentration in Wanzhou was moderate compared to major cities in China; however, taking in consideration of Wanzhou's city size, population, and economy, its $\mathrm{BC}$ contamination was concerning.

\section{Seasonal Variations of BC Concentrations}

Monthly and seasonal trends of BC during 2013-2017 were evident (Figs. 4 and 5). The lowest monthly average BC concentrations occurred in July or August, while the highest concentrations occurred in December or January. Monthly $\mathrm{BC}$ concentration varied by nearly fourfold, from a minimum of $2.3 \pm 0.5 \mu \mathrm{g} \mathrm{m}^{-3}$ (August 2017) to the maximum of $8.9 \pm$ $1.6 \mu \mathrm{g} \mathrm{m}^{-3}$ (January 2014). As shown in Fig. 4, a decreasing trend for BC was clear in all months; October and January are the main months that contributed to the decrease in annual average $\mathrm{BC}$ concentration. The decreasing trends in October and January are significant at the $95 \%$ confidence level. The peaks decreased at approximately 0.89 and $0.97 \mu \mathrm{g} \mathrm{m}^{-3}$ year $^{-1}$ in October and January, respectively. Seasonal BC concentration was highest in winter, followed by fall and spring, with summer showing the lowest concentration. Similar seasonal variation of BC concentrations can be found in other Chinese sites (Chen et al., 2014; Feng et al., 2014; Ji et al., 2016; Chen et al., 2019).

The seasonality of $\mathrm{BC}$ concentrations is mainly affected by meteorological factors and anthropogenic activities. Precipitation was usually abundant during summer (Fig. 7)

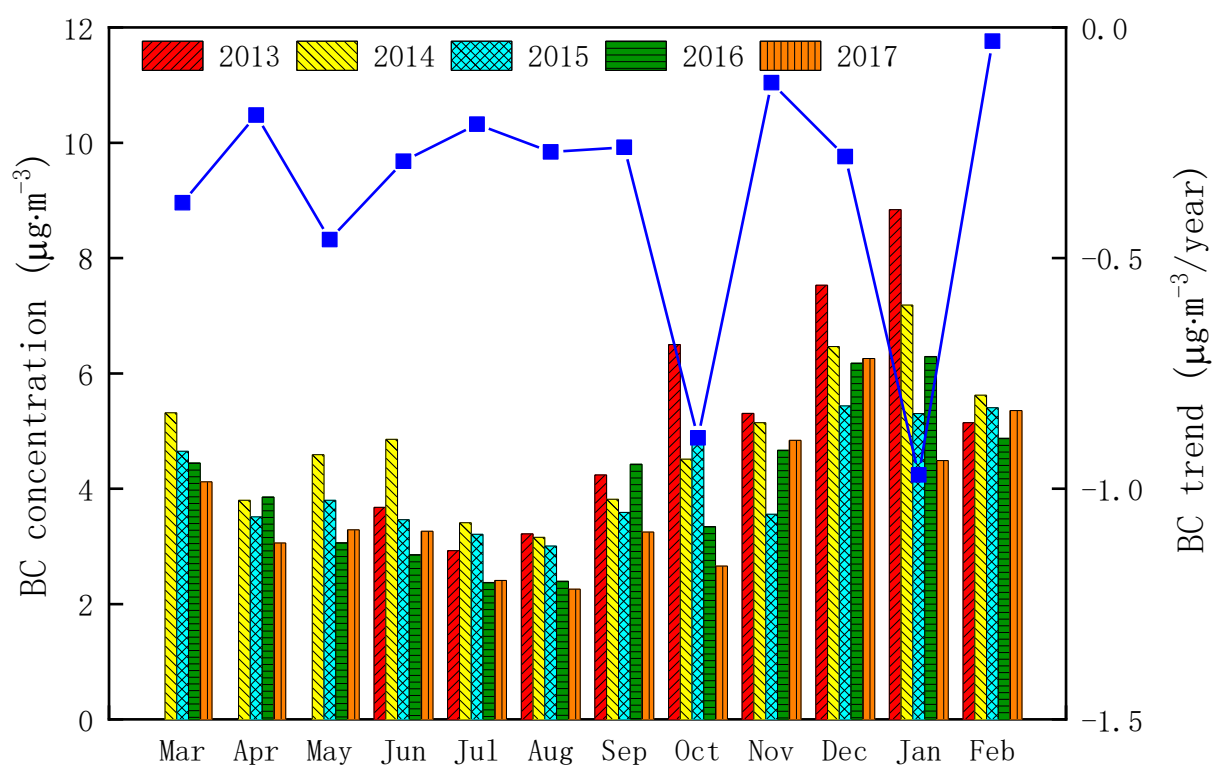

Fig. 4. Monthly average BC concentrations and BC concentration trend (blue curves) from 2013 to 2017.

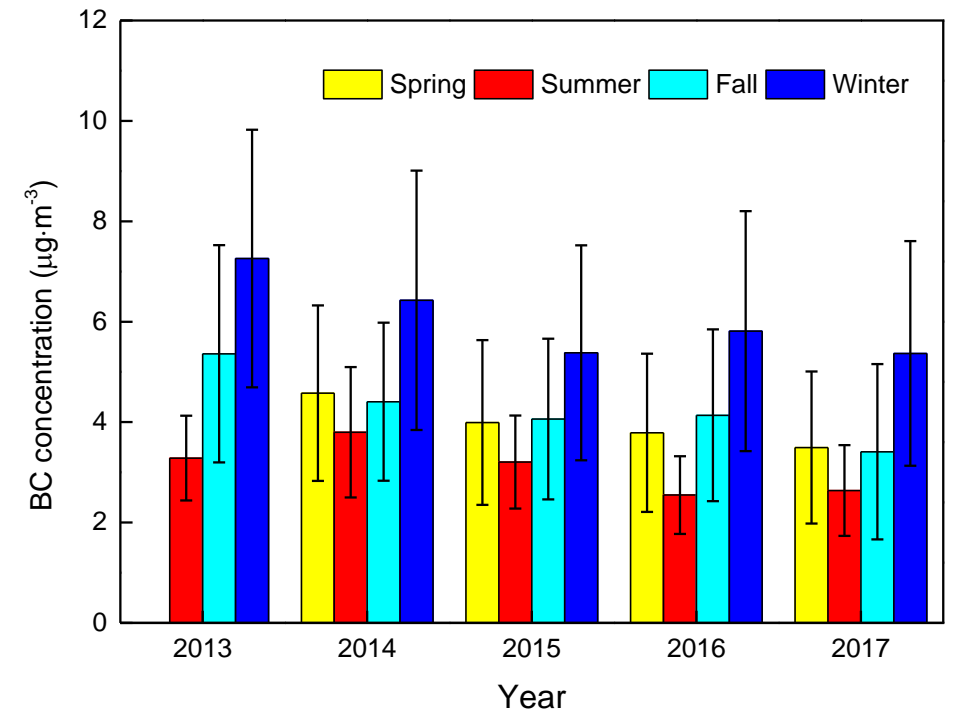

Fig. 5. Seasonal variation of $B C$ average mass concentrations (in $\mu \mathrm{g} \mathrm{m}^{-3}$ ) in Wanzhou from 2013-2018. The whiskers represent the standard deviation. Seasons are defined as: spring: March-May; summer: June-August; fall: SeptemberNovember; winter: December-February. 
and is an important mechanism that scavenges air pollutants, resulting in the lowest $\mathrm{BC}$ concentrations occurring in summer. At the same time, the PBL height was higher in summer which facilitated the dispersal of BC. Additionally, anthropogenic BC emission from fossil fuel over China was lower in summer while higher in winter (Zhuang et al., 2014; Zhang et al., 2009), also contributing to low BC concentrations in summer. High BC concentrations in fall might be due to the increased biomass burning such as burning of leftover crop residues (Huang et al., 2018). For spring, diffusion conditions were limited compared to those in summer, and could thus result in higher BC concentration than summer.

\section{Diel Variations of BC Concentrations}

The average diel $\mathrm{BC}$ mass concentrations measured in four seasons are shown in Fig. 6. In all seasons, a bimodal distribution of $\mathrm{BC}$ concentration was marked with a morning peak at 07:00-09:00 and an evening peak at 19:00 21:00. Meanwhile, the lowest BC concentration occurred between 14:00-15:00 for all seasons. This diel profile for $\mathrm{BC}$ is similar to those observed at different locations (Sahu et al., 2011; Chen et al., 2014; Feng et al., 2014). The morning peak results from morning rush hour traffic, suggesting an important role of vehicle emissions. In addition, atmospheric inversion in the morning can also lead to the high BC concentration. After sunrise, the increase in solar radiation promotes the development of daytime mixing layer, which facilitates the dispersion and dilution of pollutants, subsequently lowering $\mathrm{BC}$ concentration from morning hours. The BC evening peak could be attributed to afternoon traffic emissions and cooking, combined with low mixing heights. After midnight, due to the reduction of human activities and vehicle emissions, $\mathrm{BC}$ concentration decreased slightly, but remained at high levels. The BC concentrations

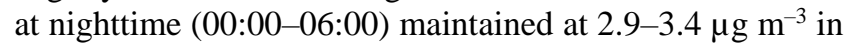

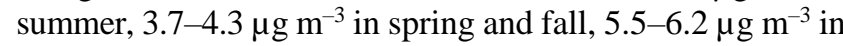
winter, respectively. This may be attributed to the formation of a nocturnal boundary layer and stagnant air flow which favor the accumulation of pollutants.

The specific timing of BC's diel variability was distinct among the seasons. The morning peak of BC concentration in winter appeared at 09:00, which was 1-2 hours later than other seasons. It could be associated with the inversion layer and the human activity regularity. During winter morning, the inversion phenomenon occurs more frequently and longer in mountain area (Wang et al., 2015b), which inhibits vertical diffusion and facilitates the accumulation of BC. Meanwhile, human activities were later than other seasons, leading to a delay in $\mathrm{BC}$ emission. In addition, the highest ratio between maximum and minimum of diel $\mathrm{BC}$ concentrations was found in summer (1.9), and the lowest in winter (1.3), reflecting the different diel variation of meteorological conditions in different seasons.

\section{Relationships to Meteorological Conditions}

PBL height, precipitation and wind speed are three important meteorological parameters affecting BC concentration. Monthly average BC mass concentration together with meteorological parameters in Wanzhou are plotted in Fig. 7. The PBL height determines the volume through which surface-emitted pollutants can be diluted and reflects boundary layer turbulence (Stull, 1988). It presented a strong seasonal variation in Wanzhou. The highest seasonal PBL height was observed in summer $(465 \mathrm{~m})$, which was 1.6 times higher than those measured in fall $(289 \mathrm{~m})$ and winter $(297 \mathrm{~m})$. A significant negative correlation coefficient $(r=-0.58)$ was found between BC concentration and PBL height, as shown in Fig. 7(a). As mentioned in Section 3.2, the average $\mathrm{BC}$ concentrations were higher in winter $\left(6.0 \mu \mathrm{g} \mathrm{m}^{-3}\right)$ than in fall $\left(4.3 \mu \mathrm{g} \mathrm{m}^{-3}\right)$. However, the PBL height was almost the same in winter and fall. This result implies that PBL height was not the main reason for the higher $\mathrm{BC}$ concentration in winter.

Precipitation is an important mechanism of washing out particles as well as BC. As shown in Fig. 7(b), most of the

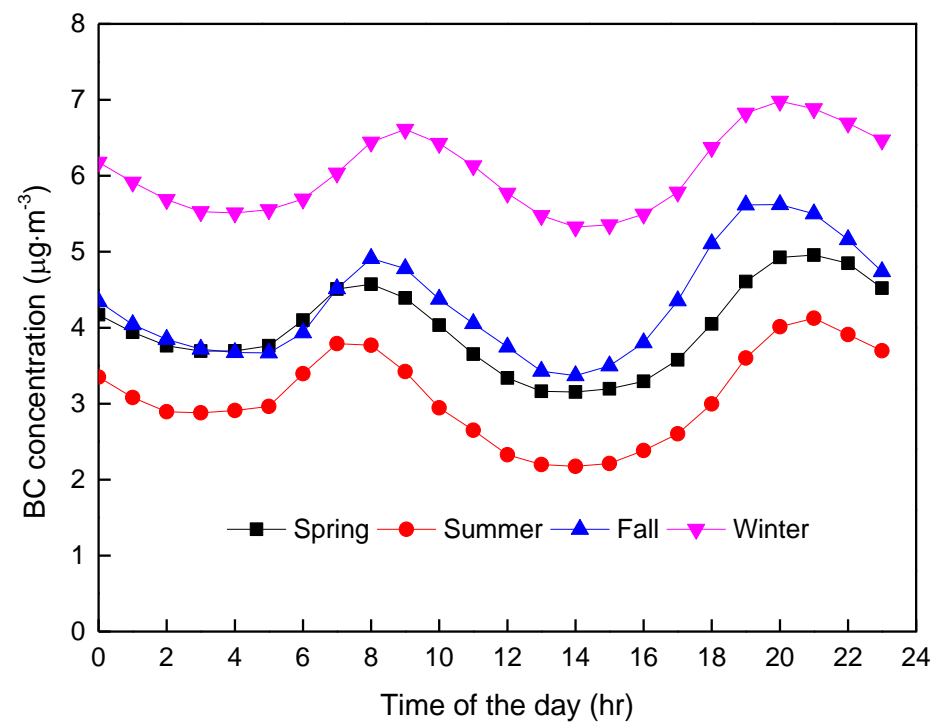

Fig. 6. Hourly average BC changes throughout the day for each season, with seasons defined in Fig. 5. 

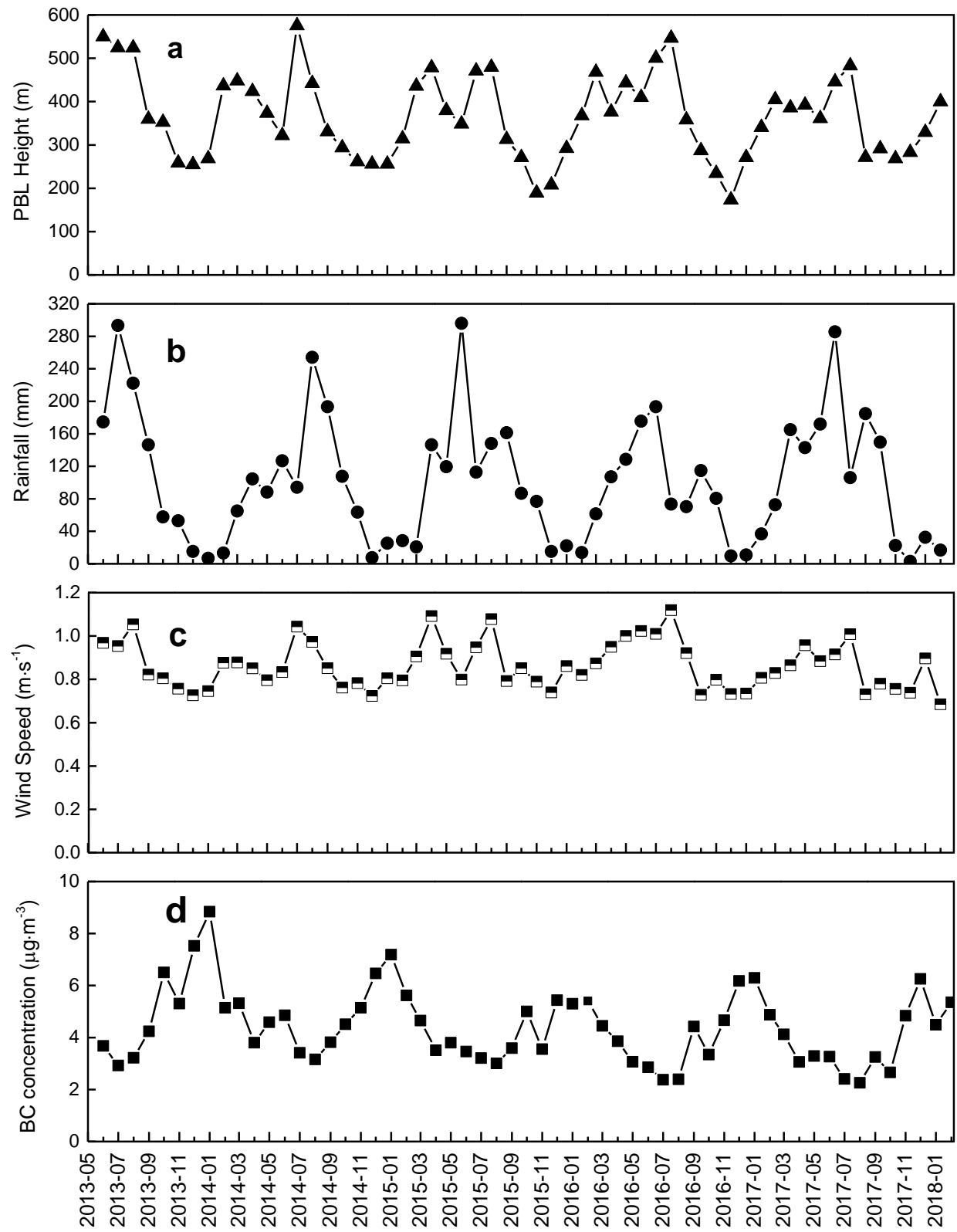

Fig. 7. Monthly average (a) planetary boundary layer (PBL) height, (b) rainfall, (c) wind speed, and (d) BC concentration in Wanzhou.

precipitation occurred between June and October in Wanzhou, accounting for 59-66\% of the annual precipitation $(1198 \mathrm{~mm})$. There was a significant negative correlation $(r=-0.74)$ between precipitation and $\mathrm{BC}$ concentration. However, a poor correlation between $\mathrm{BC}$ and rainfall was found at Xi'an $(r=-0.35)$, in northwestern China (Cao et al., 2009) and at Beijing $(r=-0.27)$ in northern China (Chen et al., 2016). This distinct feature may be due to the more frequent precipitation in southwest of China compared to the northwest (Dai et al., 2014).

Among the meteorological parameters, wind speed is an important factor determining BC concentration (Chen et al., 2014; Park et al., 2015). Fig. 7(c) shows the monthly wind speed from 2013 to 2017 . The wind speed is relatively low, with monthly averaged values generally ranged from 0.7 to
$1.1 \mathrm{~m} \mathrm{~s}^{-1}$. BC was observed to be negatively correlated with the wind speed $(r=-0.64)$. This result is similar to the findings of many previous studies (Bhat et al., 2017; Kucbel et al., 2017).

The hourly wind speeds and corresponding BC concentrations are plotted in Fig. 8. The calm conditions (wind speeds $<0.5 \mathrm{~m} \mathrm{~s}^{-1}$ ) occurred frequently in Wanzhou, accounting for $22 \%$ of the entire measurement period, during which the highest average $\mathrm{BC}$ concentration $\left(5.5 \mu \mathrm{g} \mathrm{m}^{-3}\right)$ appeared. Wind speed between 0.5 and $1 \mathrm{~m} \mathrm{~s}^{-1}$ was dominant (51\%), and the corresponding average $\mathrm{BC}$ concentration was $4.4 \mu \mathrm{g} \mathrm{m}^{-3}$. When wind speed reached $1.5-2.0 \mathrm{~m} \mathrm{~s}^{-1}$, the average $\mathrm{BC}$ concentration dropped to $3.0 \mu \mathrm{g} \mathrm{m}^{-3}(45 \%$ reduction). A clear inverse relationship between $\mathrm{BC}$ concentration and wind speed was found for wind speed 


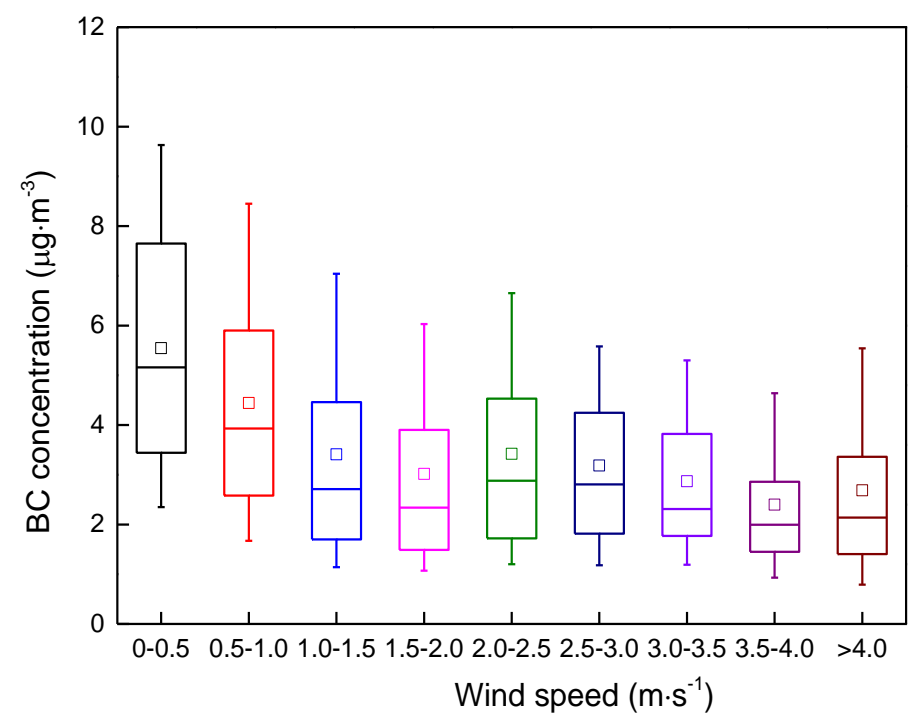

Fig. 8. BC concentration intervals grouped by wind speed. Box-and-whisker plot indicates median and 25\% quartile (box), mean (square), 10/90\% (whiskers).

lower than $2.0 \mathrm{~m} \mathrm{~s}^{-1}$. However, when the wind speed was higher than $2.0 \mathrm{~m} \mathrm{~s}^{-1}$, no clear relation between wind speed and $\mathrm{BC}$ concentrations could be seen. Similar relationship between $\mathrm{BC}$ and wind speed have also been reported for other urban locations globally, such as Helsinki, Finland (Pakkanen et al., 2000), and Urumqi, China (Li et al., 2012).

The contribution of hourly $\mathrm{BC}$ from different wind directions is illustrated by wind rose plots in Fig. 9. The prevailing winds in Wanzhou were mainly from eastern and southeastern directions in different seasons. The main road, Shalong Road, is located to the east of the sampling site, so it can be speculated that the higher $\mathrm{BC}$ concentration from this direction may be affected by traffic emissions. Since the local industrial area lies in southeastern Wanzhou, relatively high $\mathrm{BC}$ concentration from this direction was likely due to the influence from industrial emissions. In addition, it is noteworthy that frequencies of wind directions between $180^{\circ}$ to $270^{\circ}$ increased in fall and winter, and $\mathrm{BC}$ concentration observed by these directions was considerably high. Patches of farmlands lie to the west of the sampling site; higher $\mathrm{BC}$ concentration from these directions could be attributed to the burning of crop residues on these farmlands.

The conditional probability function (CPF) was used to identify the likely locations of local emission sources affecting concentrations of $\mathrm{BC}$ in sampling site. $\mathrm{BC}$ data obtained at wind speeds $<1.0 \mathrm{~m} \mathrm{~s}^{-1}$ were excluded in the $\mathrm{CPF}$ analysis due to the isotropic behavior of wind vane under low wind speeds. Fig. 10 shows the CPF concentration plots of BC when the threshold was set at the upper $25^{\text {th }}$ percentile of the concentrations. The emission sources are likely located in the directions that have high conditional probability values. There was a clear indication of higher probability for these concentrations from the southeast, i.e., in the direction of industrial emissions. Additionally, there was high probability to the west, corresponding to the direction where some farmlands lie. Combining Fig. 10 with Fig. 9 produces an interesting feature: The highest concentration occurred under very low wind speed conditions from all wind directions, particularly the east, corresponding to the direction where the main road lies. Thus, it is suggestive that $\mathrm{BC}$ concentration was mainly affected by traffic emissions at low wind speed $\left(<1.0 \mathrm{~m} \mathrm{~s}^{-1}\right)$, while $\mathrm{BC}$ concentration was affected by transport from industrial emissions and biomass burning at high wind speed $\left(>1.0 \mathrm{~m} \mathrm{~s}^{-1}\right)$.

\section{CONCLUSIONS}

In this study, BC was measured in Wanzhou metropolitan area from June 2013 till February 2018 in order to investigate its temporal variability and potential sources. The average daily concentration ranged from 0.5 to $10.4 \mu \mathrm{g} \mathrm{m}^{-3}$, with a mean of $4.4 \pm 2.2 \mu \mathrm{g} \mathrm{m}^{-3}$, and the average annual concentration exhibited a declining trend, decreasing from $5.3 \mu \mathrm{g} \mathrm{m}^{-3}$ in 2013 to $3.7 \mu \mathrm{g} \mathrm{m}^{-3}$ in 2017 . Although these values qualify as moderate in China, BC contamination is nevertheless an issue when considering the size, population, and economy of Wanzhou. The seasonality of the $\mathrm{BC}$ - specifically, the occurrence of the minimum and maximum concentrations during summer and winter, respectively - can be attributed to changes in the emission sources and variability in the ambient meteorological conditions, especially the low precipitation and shallow PBL height during winter. The concentrations peaked during the morning between 07:00 and 09:00 and again during the evening between 19:00 and 21:00, likely as a result of anthropogenic activities, including traffic, and dropped to their lowest daily values between 14:00 and 15:00, which can be ascribed to the development of the PBL.

The $\mathrm{BC}$ concentration was found to be negatively correlated with the PBL height $(r=-0.58)$, rainfall $(r=-0.74)$, and wind speed $(r=-0.64)$. Furthermore, winds blowing from the east and southeast, the most frequent directions, were accompanied by higher concentrations during all of the seasons, and CPF analysis indicated a high probability of sources to the southeast, where industry is located, and to 

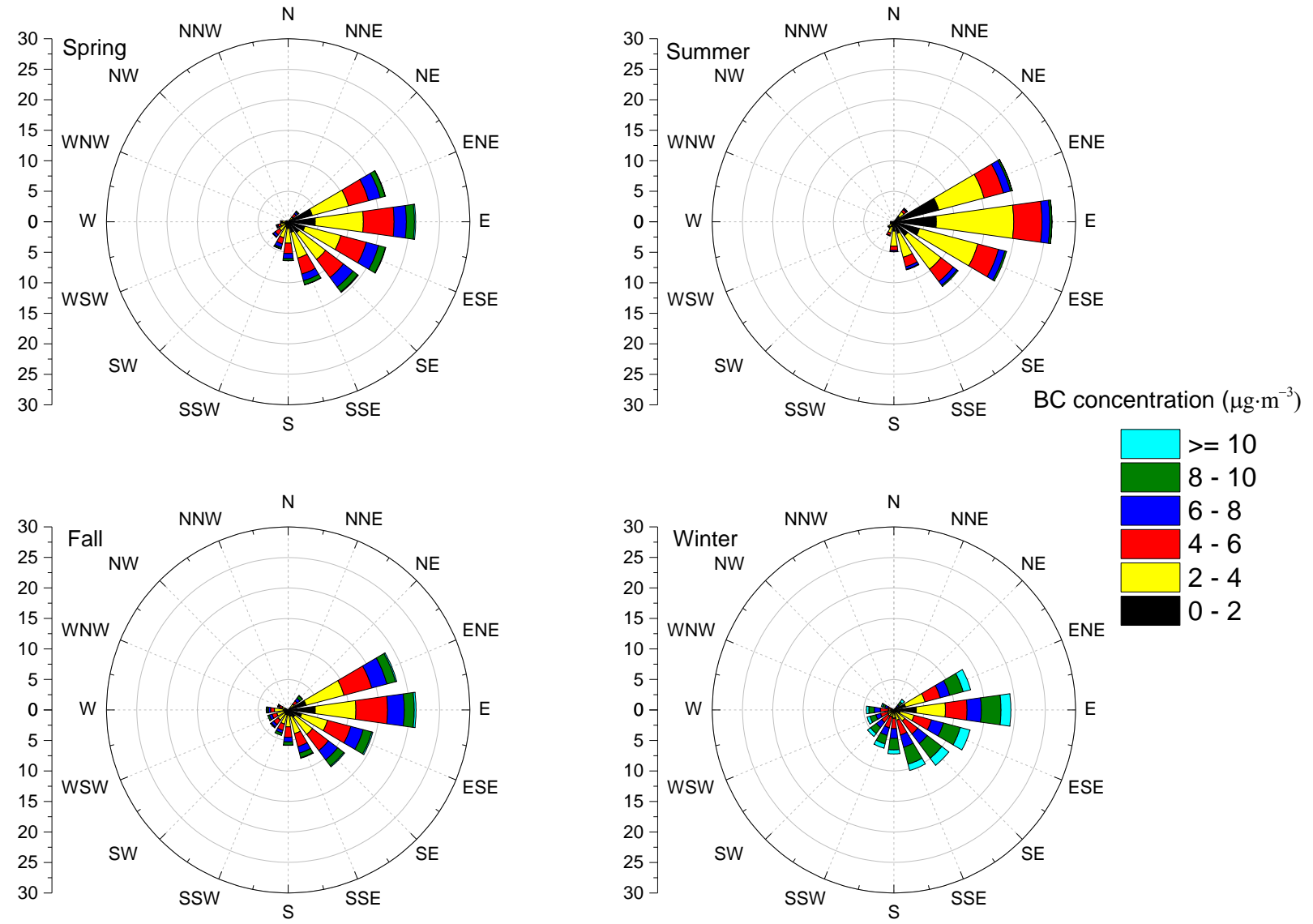

Fig. 9. Hourly BC concentrations with wind direction during four seasons. The scales display the percentage frequencies of wind directions. The legends display BC concentrations $\left(\mu \mathrm{g} \mathrm{m}^{-3}\right)$.

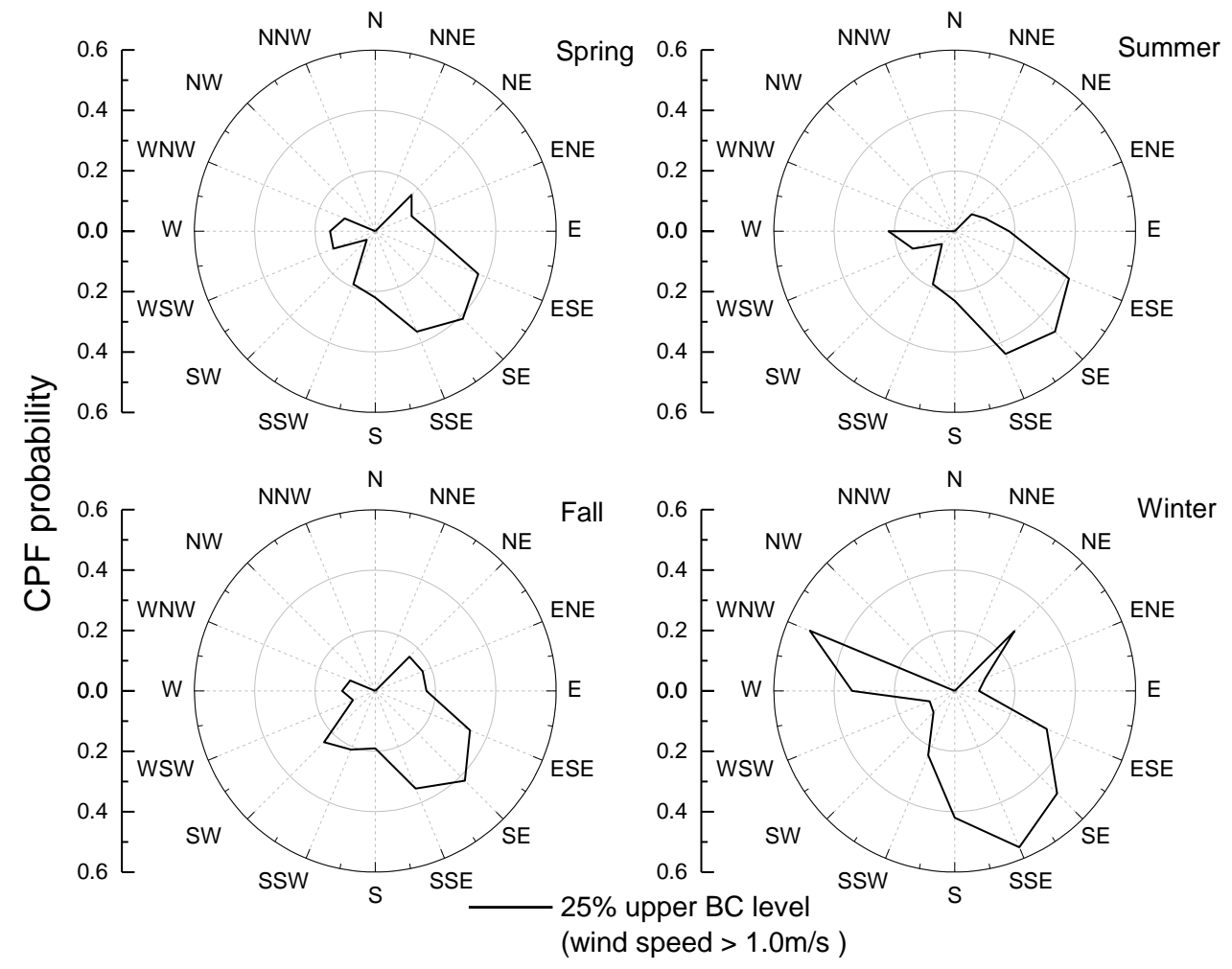

Fig. 10. CPF plots for $\mathrm{BC}$ at $75 \%$ percentile in different seasons. 
the west, where farmlands lie. Thus, at low wind speeds $\left(<1.0 \mathrm{~m} \mathrm{~s}^{-1}\right)$, traffic emissions may have been the primary factor influencing the $\mathrm{BC}$ concentration, whereas at high wind speeds $\left(>1.0 \mathrm{~m} \mathrm{~s}^{-1}\right)$, industrial emissions and biomass burning potentially played the largest roles.

\section{ACKNOWLEDGMENTS}

This research was funded by the National Natural Science Foundation of China (41375123), Fundamental Research Funds for the Central Universities (YJ201891), Science and Technology Commission of Chongqing Project (Grant No. cstc2018jcyjAX0236), Scientific and Technological Research Program of Chongqing Municipal Education Commission, and Chongqing Three Gorges University project (Grant No. 19QN03).

\section{REFERENCES}

Bhat, M.A., Romshoo, S.A. and Beig, G. (2017). Aerosol black carbon at an urban site-Srinagar, Northwestern Himalaya, India: Seasonality, sources, meteorology and radiative forcing. Atmos. Environ. 165: 336-348. https://doi.org/10.1016/j.atmosenv.2017.07.004

Bond, T.C., Bhardwaj, E., Dong, R., Jogani, R., Jung, S.K., Roden, C., Streets, D.G. and Trautmann, N.M. (2007). Historical emissions of black and organic carbon aerosol from energy-related combustion, 1850-2000. Global Biogeochem. Cycles 21: GB2018. https://doi.org/10.1029 /2006GB002840

Cao, J.J., Zhu, C.S., Chow, J.C., Watson, J.G., Han, Y.M., Wang, G.H., Shen, Z.X. and An, Z.S. (2009). Black carbon relationships with emissions and meteorology in Xi'an, China. Atmos. Environ. 94: 194-202. https://doi.org/ 10.1016/j.atmosres.2009.05.009

Chameides, W.L., Yu, H., Liu, S.C., Bergin, M., Zhou, X., Mearns, L., Wang, G., Kiang, C.S., Saylor, R.D., Luo, C., Huang, Y., Steiner, A. and Giorgi, F. (1999). Case study of the effects of atmospheric aerosols and regional haze onagriculture: an opportunity to enhance crop yields in China through emission controls? Proc. Natl. Acad. Sci. U.S.A. 96: 13626-13633. https://doi.org/10.1073/pnas.96. 24.13626

Chen, W., Tian, H. and Qin, K. (2019). Black carbon aerosol in the industrial city of Xuzhou, China: Temporal characteristics and source appointment. Aerosol Air Qual. Res. 19: 794-811. https://doi.org/10.4209/aaqr.2018.07. 0245

Chen, X.C., Zhang, Z.S., Engling, G., Zhang, R.J., Tao, J., Lin, M., Sang, X.F., Chan, C.Y., Li, S.Y. and Li, Y.P. (2014). Characterization of fine particulate black carbon in Guangzhou, a megacity of south China. Atmos. Pollut. Res. 5: 361-370. https://doi.org/10.5094/APR.2014.042

Chen, Y., Schleicher, N., Fricker, M., Cen, K., Liu, X.L., Kaminski, U., Yang, Y., Xue, F.W. and Norra, S. (2016). Long-term variation of black carbon and $\mathrm{PM}_{2.5}$ in Beijing, China with respect to meteorological conditions and governmental measures. Environ. Pollut. 212: 269-278. https://doi.org/10.1016/j.envpol.2016.01.008
Chow, J.C., Watson, J.G., Doraiswamy, P., Chen, L.W.A., Sodeman, D.A., Lowenthal, D.H., Park, K., Arnott, W.P. and Motallebi, N. (2009). Aerosol light absorption, black carbon, and elemental carbon at the Fresno Supersite, California. Atmos. Res. 93: 874-887. https://doi.org/10.10 16/j.atmosres.2009.04.010

Chung, S.H. and Seinfeld, J.H. (2005). Climate response of direct radiative forcing of anthropogenic black carbon. $J$. Geophys. Res. 110: D11102. https://doi.org/10.1029/2004 JD005441

Dai, Z.Y., Jiang, J. and Xiao, M.K. (2014). Autocorrelation analysis on China's rainfall based on the improved spatiotemporal Moran's I. J. Huazhong Normal Univ. 48: 924929.

Dalirian, M., Ylisirniö, A., Buchholz, A., Schlesinger, D., Ström, J., Virtanen, A. and Riipinen, I. (2017). Cloud droplet activation of black carbon particles coated with organic compounds of varying solubility. Atmos. Chem. Phys. 18: 12477-12489. https://doi.org/10.5194/acp-1812477-2018

Farzad, K., Khorsandi, B., Khorsandi, M., Bouamra, O. and Maknoon, R. (2020). A study of cardiorespiratory related mortality as a result of exposure to black carbon. Sci. Total Environ. 725: 138422. https://doi.org/10.1016/j.sci totenv.2020.138422

Feng, J., Zhong, M., Xu, B., Du, Y., Wu, M., Wang, H. and Chen, C. (2014). Concentrations, seasonal and diurnal variations of black carbon in $\mathrm{PM}_{2.5}$ in Shanghai, China. Atmos. Res. 147-148: 1-9. https://doi.org/10.1016/j.atmo sres.2014.04.018

Huang, X.F., Sun, T.L., Zeng, L.W., Yu, G.H. and Luan, S.J. (2012). Black carbon aerosol characterization in a coastal city in South China using a single particle soot photometer. Atmos. Environ. 51: 21-28. https://doi.org/10. 1016/j.atmosenv.2012.01.056

Huang, Y.M., Liu, Y., Zhang, L.Y., Peng, C. and Yang, F.M. (2018). Characteristics of carbonaceous aerosol in $\mathrm{PM}_{2.5}$ at Wanzhou in the southwest of China. Atmoshpere 9: 37. https://doi.org/10.3390/atmos9020037

Jacobson, M.Z. (2001). Strong radiative heating due to mixing state of black carbon in atmospheric aerosol. Nature. 409: 695-697. https://doi.org/10.1038/35055518

Jacobson, M.Z. (2002). Control of fossil-fuel particulate black carbon and organic matter, possibly the most effective method of slowing global warming. J. Geophys. Res. 107. https://doi.org/10.1029/2001JD001376

Janssen, N.A.H., Hoek, G., Simic-Lawson, M., Fischer, P., Bree, L.V., Brink, H.T., Keuken, M., Atikinson, R.W., Anderson, H.R., Brunekreef, B. and Flemming, R. (2011). Black carbon as an additional indicator of the adverse health effects of airborne particles compared with $\mathrm{PM}_{10}$ and $\mathrm{PM}_{2.5}$. Environ. Health Perspect. 119: 16911699. https://doi.org/10.1289/ehp.1003369

Ji, D., Zhang, J., He, J., Wang, X., Pang, B., Liu, Z., Wang, L. and Wang, Y. (2016). Characteristics of atmospheric organic and elemental carbon aerosols in urban Beijing, China. Atmos. Environ. 125: 293-306. https://doi.org/10. 1016/j.atmosenv.2015.11.020

Ji, D., Li, L., Pang, B., Xue, P., Wang, L., Wu, Y., Zhang, H. 
and Wang, Y. (2017). Characterization of black carbon in an urban-rural fringe area of Beijing. Environ. Pollut. 223: 524-534. https://doi.org/10.1016/j.envpol.2017.01.055

Ji, D., Gao, M., Maenhaut, W., He, J., Wu, C., Cheng, L., Gao, W., Sun, Y., Sun, J., Xin, J., Wang, L. and Wang, Y. (2019a). The carbonaceous aerosol levels still remain a challenge in the Beijing-Tianjin-Hebei region of China: insights from continuous high temporal resolution measurements in multiple cities. Environ. Int. 126: 171183. https://doi.org/10.1016/j.envint.2019.02.034

Ji, D., Gao, W., Maenhaut, W., He, J., Wang, Z., Li, J., Du, W., Wang, L., Sun, Y., Xin, J., Hu, B. and Wang, Y. (2019b). Impact of air pollution control measures and regional transport on carbonaceous aerosols in fine particulate matter in urban Beijing, China: insights gained from long-term measurement. Atmos. Chem. Phys. 19: 8569-8590. https://doi.org/10.5194/acp-19-8569-2019

Jung, K.H., Lovinsky-Desir, S., Yan, B., Torrone, D., Lawrence, J., Jezioro, J.R., Perzanowski, M., Perera, F.P., Chillrud, S.N. and Miller, R.L. (2017). Effect of personal exposure to black carbon on changes in allergic asthma gene methylation measured 5 days later in urban children: Importance of allergic sensitization. Clin. Epigenet. 9: 61. https://doi.org/10.1186/s13148-017-0361-3

Kanaya, Y., Taketani, F., Komazaki, Y., Liu, X., Kondo, Y., Sahu, L.K., Irie, H. and Takashima, H. (2013). Comparison of black carbon mass concentrations observed by MultiAngle Absorption Photometer (MAAP) and Continuous Soot-Monitoring System (COSMOS) on Fukue Island and in Tokyo, Japan. Aerosol Sci. Technol. 47: 1-10. https://doi.org/10.1080/02786826.2012.716551

Kopp, R.E. and Mauzerall, D.L. (2010). Assessing the climatic benefits of black carbon mitigation. Proc. Natl. Acad. Sci. U.S.A. 107: 11703-11708. https://doi.org/10.1 073/pnas.0909605107

Kucbel, M., Corsaro, A., Švédová, B., Raclavská, H., Raclavský, K. and Juchelková, D. (2017). Temporal and seasonal variations of black carbon in a highly polluted Europeas city: apportionment of potential sources and the effect of meteorological conditions. J. Environ. Manage. 203: 1178-1189. https://doi.org/10.1016/j.jenvman.2017. 05.038

Li, S., Guo, Z.Z., Hu, L.Q., He, Q. and Xu, Z.D. (2012). Preliminary study on black carbon aerosol pollution over Urumqi in Winter. Arid Zone Res. 29: 728-734. (in Chinese with English Abstract)

Liu, Z.R., Gao, W.K., Yu, Y.C., Hu, B., Xin, J.Y., Sun, Y., Wang, L.L., Wang, G.H., Bi, X.H., Zhang, G.H., Xu, H.H., Cong, Z.Y., He, J., Xu, J.S. and Wang, Y.S. (2018). Characteristics of $\mathrm{PM}_{2.5}$ mass concentrations and chemical species in urban and background areas of China: Emerging results from the CARE-China network. Atmos. Chem. Phys. Discuss. 18: 1-34. https://doi.org/10.5194/ acp-2017-1232

Liu, Z.R., Hu, B., Ji, D.S., Cheng, M.T., Gao, W.K., Shi, S.Z., Xie, Y.Z., Yang, S.H., Gao, M., Fu, H.B., Chen, J.M. and Wang, Y.S. (2019). Characteristics of fine particle explosive growth events in Beijing, China: Seasonal variation, chemical evolution pattern and formation mechanism. Sci. Total Environ. 687: 10731086. https://doi.org/10.1016/j.scitotenv.2019.06.068

Menon, S., Hansen, J., Nazarenko, L. and Luo, Y.F. (2002). Climate effects of black carbon aerosols in China and India. Science 297: 2250-2253. https://doi.org/10.1126/s cience. 1075159

Novakov, T., Ramanathan, V., Hansen, J.E., Kirchstetter, T.W., Sato, M., Sinton, J.E. and Sathaye, J.A. (2003). Large historical changes of fossil-fuel black carbon aerosols. Geophys. Res. Lett. 30. https://doi.org/10.1029/ $2002 \mathrm{gl} 1016345$

Pakkanen, T.A., Kerminen, V.M., Ojanen, C.H., Hillamo, R.E., Aarnio, P. and Koskentalo, T. (2000). Atmospheric black carbon in Helsinki. Atmos. Environ. 34: 1497-1506. https://doi.org/10.1016/S0021-8502(98)00362-0

Panicker, A.S., Park, S.H., Lee, D.I., Kim, D.C., Jung, W.S., Jang, S.M., Jeong, J.H., Kim D.S., Yu, J. and Jeong, H. (2013). Observations of black carbon characteristics and radiative forcing over a global atmosphere watch supersite in Korea. Atmos. Environ. 77: 98-104. https://doi.org/10. 1016/j.atmosenv.2013.04.020

Park, S.S. and Lee, K.H. (2015). Characterization and sources of black carbon in $\mathrm{PM}_{2.5}$ at a site close to a roadway in Gwangju, Korea, during winter. Environ. Sci. Processes Impacts 17: 1794-805. https://doi.org/10.1039 $/ \mathrm{c} 5 \mathrm{em} 00225 \mathrm{~g}$

Peng, X., Liu, M., Zhang, Y., Meng, Z., Achal, V., Zhou, T., Long, L. and She, Q. (2019). The characteristics and local-regional contributions of atmospheric black carbon over urban and suburban locations in Shanghai, China. Environ. Pollut. 255: 113188. https://doi.org/10.1016/j.e nvpol.2019.113188

Qi, M.Y., Wang, L.T., Zhang, C.Y., Ma, X., Zhao, L., Ji, S.P., Lu, X. and Wang, Y. (2018). Variation of black carbon aerosol concentration and its influencing factors in Handan City, Hebei Province. Acta Sci. Circumat. 38: 1751-1758. (in Chinese with English Abstract)

Quaas, J. (2011). The soot factor. Nature 471: 456-457. https://doi.org/10.1038/471456a

Rai, M., Mahapatra, S.P., Gul. C., Kayastha, R.B., Panday, A.K. and Puppala, S.P. (2019). Aerosol radiative forcing estimation over a remote high-altitude location $(\sim 4900$ masl) near Yala Glacier, Nepal. Aerosol Air Qual. Res. 19: 1872-1891. https://doi.org/10.4209/aaqr.2018.09.0342

Ramachandran, S. and Rajesh, T.A. (2007). Black carbon aerosol mass concentrations over Ahmedabad, an urban location in western India: comparison with urban sites in Asia, Europe, Canada, and the United States. J. Geophys. Res. 112: D06211. https://doi.org/10.1029/2006JD007488

Ramanathan, V. and Carmichael, G. (2008). Global and regional climate changes due to black carbon. Nat. Geosci. 1: 221-227. https://doi.org/10.1038/ngeo156

Richardson, T.B., Forster, P.M., Andrews, T., Boucher, O., Faluvegi, G., Fläschner, D., Hodnebrog, Ø., Kasoar, M., Kirkevåg, A., Lamarque, J.F. Myhre, G., Olivié, D., Samset, B.H., Shawki, D., Shindell, D., Takemura, T. and Voulgarakis, A. (2018). Drivers of precipitation change: An energetic understanding. J. Clim. 31: 9641-9657. https://doi.org/10.1175/JCLI-D-17-0240.1 
Sahu, L.K., Kondo, Y., Miyazaki, Y., Pongkiatkul, P. and Oanh, N.T.K. (2011). Seasonal and diurnal variations of black carbon and organic carbon aerosols in Bangkok. $J$. Geophys. Res. 116: D15302. https://doi.org/10.1029/201 0JD015563

Schmidt, C.W. (2011). Black carbon: The dark horse of climate change drivers. Environ. Health Perspect. 119: 172-175. https://doi.org/10.1289/ehp.119-a172

Streets, D.G., Gupta, S., Waldhoff, S.T., Wang, M.Q., Bond, T.C. and Yiyun, B. (2001). Black carbon emissions in China. Atmos. Environ. 35: 4281-4296. https://doi.org/10. 1016/S1352-2310(01)00179-0

Stull, R.B. (1988). An introduction to boundary layer meteorology. Springer Netherlands.

Sun, H.H., Ni, C.J. and Cui, L. (2016). Characteristics of black carbon aerosol pollution in Chengdu and the relationship between meteorological factors. Environ. Eng. 34: 11-124. (in Chinese with English Abstract)

Sun, J.Y., Wu, C., Wu, D., Cheng, C., Li, M., Li, L., Deng, T., Yu, J.Z., Li, Y.J., Zhou, Q., Liang, Y., Sun, T., Song, L., Cheng, P., Yang, W., Pei, C., Chen, Y., Cen, Y., Nian, H. and Zhou, Z. (2020). Amplification of black carbon light absorption induced by atmospheric aging: temporal variation at seasonal and diel scales in urban Guangzhou. Atmos. Chem. Phys. 20: 2445-2470. https://doi.org/10.51 94/acp-20-2445-2020

Tian, P., Zhang, L., Ma, J., Tang, K., Xu, L., Wang, Y., Cao, X., Liang, J., Ji, Y., Jiang, J.H., Yung, Y.L. and Zhang, R.Y. (2018). Radiative absorption enhancement of dust mixed with anthropogenic pollution over East Asia. Atmos. Chem. Phys. 18: 7815-7825. https://doi.org/10.51 94/acp-18-7815-2018

Wang, Q., Huang, R., Cao, J., Tie, X., Shen, Z., Zhao, S., Han, Y., Li, G., Li, Z., Ni, H., Zhou, Y., Wang, M., Chen, Y. and Su, X. (2016). Contribution of regional transport to the black carbon aerosol during winter haze period in Beijing. Atmos. Environ. 132: 11-18. https://doi.org/10.1 016/j.atmosenv.2016.02.031

Wang, Q.Y., Liu, S.X., Zhou, Y.Q., Cao, J.J., Han, Y.M., Ni, H.Y., Zhang, N.N. and Huang, R.J. (2015a). Characteristics of black carbon aerosol during the Chinese Lunar Year and Weekdays in Xi'an, China. Atmosphere 6: 195-208. https://doi.org/10.3390/atmos60 20195

Wang, X., Zeng, Y. and Qiu, X.F. (2015b). Temperature inversion in mountain areas based on distributed simulation of monthly mean temperature under complex terrains. Sci. Technol. Eng. 15: 1-7. (in Chinese with English Abstract)

Wang, Y., Hopke, P.K., Rattigan, O.V. and Zhu, Y. (2011). Characterization of ambient black carbon and wood burning particles in two urban areas. J. Environ. Monit.
13: 1919-1926. https://doi.org/10.1039/C1EM10117J

Xiao, S.H., Yu, X.N., Zhu, B. and He, J.Q. (2016). Characteristics of black carbon aerosol and influencing factors in northern suburbs of Nanjing. Environ. Sci. 37: 3280-3289. (in Chinese with English Abstract) https://doi.org/10.13227/j.hjkx.2016.09.005

Zhang, C., Zhou, Z.E., Zhai, C.Z., Chen, G.C., Zhang, D., Yu, J.Y., Zheng, J.J. and Wu, L.P. (2014). Characteristics and influencing factors of black carbon aerosol in Chongqing. Acta Sci. Circumat. 34: 812-818. (in Chinese with English Abstract) https://doi.org/10.13671/j.hjkxxb. 2014.0137

Zhang, Q., Streets, D.G., Carmichael, G.R., He, K., Huo, H., Kannari, A., Klimont, Z., Park, I., Reddy, S., Fu, J.S., Chen, D., Duan, L., Lei, Y., Wang, L. and Yao, Z. (2009). Asian emissions in 2006 for the NASA INTEX-B mission. Atmos. Chem. Phys. 9: 5131-5153. https://doi.org/10.5194 /acp-9-5131-2009

Zhang, Q., Shen, Z.X., Cao, J.J., Zhang, R.J., Zhang, L.M., Huang, R.J., Zheng, C.J., Wang, L.Q., Liu, S.X., Xu, H.M., Zheng, C. and Liu, P. (2015). Variations in $\mathrm{PM}_{2.5}$, TSP, $\mathrm{BC}$, and trace gases $\left(\mathrm{NO}_{2}, \mathrm{SO}_{2}\right.$, and $\left.\mathrm{O}_{3}\right)$ between haze and non-haze episodes in winter over Xi'an, China. Atmos. Environ. 112: 64-71. https://doi.org/10.1016/j.atm osenv.2015.04.033

Zhang, Q., Shen, Z., Lei, Y., Wang, Y., Zeng, Y., Wang, Q., Ning, Z., Cao, J., Wang, L. and Xu, H. (2018). Variations of particle size distribution, black carbon, and brown carbon during a severe winter pollution event over Xi'an, China. Aerosol Air Qual. Res. 18: 1419-1430. https://doi.org/10.4209/aaqr.2018.01.0007

Zhao, Y.C., Deli, G., Cai, Y.X., Zhang, Z.F. and Wen, Y.P. (2008). Variation of black-carbon aerosol concentration observed in Xining. J. Glaciol. Geocryol. 30: 789-794. (in Chinese with English Abstract)

Zhou, B., Wang, Q., Zhou, Q., Zhang, Z., Wang, G., Fang, N., Li, M. and Cao, J. (2018). Seasonal characteristics of black carbon aerosol and its potential source regions in Baoji, China. Aerosol Air Qual. Res. 18: 397-406. https://doi.org/10.4209/aaqr.2017.02.0070

Zhuang, B.L., Wang, T.J., Liu, J., Li, S., Xie, M., Yang, X.Q., Fu, C.B., Sun, J.N., Yin, C.Q., Liao, J.B., Zhu, J.L. and Zhang, Y. (2014). Continuous measurement of black carbon aerosol in urban Nanjing of Yangtze river delta, China. Atmos. Environ. 89: 415-424. https://doi.org/10.1 016/j.atmosenv.2014.02.052

Received for review, January 2, 2020 Revised, April 25, 2020 Accepted, April 25, 2020 